\title{
Methanogenic and fertilizing potential of aquaculture waste: towards freshwater farms energy self- sufficiency in the framework of blue growth
}

Ndiaye Ndeye Aida 1, 2, Maiguizo-Diagne Halima ${ }^{1}$, Diadhiou Hamet Diaw ${ }^{3}$, Ndiaye Waly Ndianco ${ }^{3,4}{ }^{*}$, Diedhiou Fulgence $^{3}$, Cournac Laurent ${ }^{2,5}$, Gaye Mohamed Lamine ${ }^{6}$, Fall Saliou ${ }^{1}$, Brehmer Patrice ${ }^{3,7,{ }^{*}}$

${ }^{1}$ LCM - LAPSE Institut Sénégalais de Recherches Agricoles (ISRA) Dakar, Senegal

2 LMI IESOL LEMSAT ,Centre IRD-ISRA-UCAD Bel Air Dakar, Senegal

${ }^{3}$ Dakar-Thiaroye Oceanographic Research Center (CRODT), ISRA Research Center of Hann (PRH) Institut Sénégalais de Recherches Agricoles (ISRA) Dakar ,Senegal

${ }^{4}$ Département Sciences Animales ,Faculté des sciences de l'agriculture et de l'alimentation Université Laval Québec ,Canada

${ }^{5}$ Eco\&Sols IRD CIRAD INRA Montpellier Supagro Univ Montpellier Montpellier, France

${ }^{6}$ Department of Chemistry, University Cheikh Anta DIOP (UCAD) Dakar, Senegal

7 IRD, Univ Brest CNRS Ifremer IUEM-Lemar Plouzané , France

* Corresponding authors : Waly Ndianco Ndiaye, email address : walyndiaye16@outlook.com ; Patrice Brehmer, email address : Patrice.Brehmer@ird.fr

\begin{abstract}
:
he fisheries sector, particularly aquaculture, is a fundamental source of nutrition for humans, particularly in developing countries. The modern development of fish farming requires energy for production systems. This study investigates the potential of using organic wastes derived from fish fattening to produce onfarm energy through the process of methanization. Oreochromis niloticus faeces methanogen potential was determined with (IFF) and without (UIFF) methanizer microbial inoculum. At the end of the manure methanation trials, the resulting digestates were tested as organic fertilizers for agriculture. The tests showed that inoculated fish faeces had faster biogas kinetics production compared with uninoculated fish faeces. In both cases, the produced biogas contained more than $60 \%$ methane $(\mathrm{CH} 4)$ from the second week of incubation, indicating that it was of good quality. Furthermore, the total $\mathrm{CH} 4$ volume was twice as larger in IFF compared with UIFF. Biofertilizer tests showed no significant differences for most of the growth parameters in onion and tomato when compared to the unfertilized control, except in one case for tomato plants, which significantly increased its aboveground biomass. The results show that fish faeces are good methanogenic substrates conducive to energy recovery that could facilitate farm autonomy; however, valorization of the digestates as biofertilizer still requires extensive agronomic optimization. Based on our results, we estimate that equivalents of energy need of almost ten millions of people could be covered using the aquaculture potential in freshwater fish faeces biogas worldwide or that at least aquaculture farm energy self-sufficiency could be fostered.
\end{abstract}

Keywords : biogas, digests, energy recovery, fish faeces, methanation, sustainable science 


\section{Introduction}

In the framework of blue growth (Burgess et al. 2018) many initiatives are supported around the world to foster innovative approach environmentally compatible integrated and socioeconomically sensitive management of aquatic resources (Moffitt \& Cajas-Cano 2014). In the case of Senegal fishing is carried out at sea, in estuaries, rivers, floodplains around hydroagricultural dams, in the Senegal River valley and Casamance (Anambé Basin) by professionals and casual fishers (Dème et al. 2005; Auger et al. 2016; Tiedemann \& Brehmer, 2017). Senegalese fishermen mainly operate at sea aboard motorized canoes (Diankha et al. 2017), with a small contribution by industrial fishing vessels. The fishing sector plays an essential role in the economy of Senegal. This sector provides food and nutritional security to the population, supplying nearly $75 \%$ of animal protein sources (Ba et al. 2017). Moreover, this sector is of socio-economic importance because of the numerous employment it generates. The landings of the industrial fishery were estimated at 92,251 tons in 2017 , with a commercial value at first sale estimated as 62 billion francs CFA (Communauté Financière Africaine; currency code XOF). The artisanal marine fishery captured 439,080 tons of fish in 2017 , with a commercial value on the landing of about 164.464 billion francs CFA (MPEM, 2018). Overall, sea fishing contributed around 3.5\% Gross Domestic Product (GDP) in 2017 and directly employed 15\% of the active population in 2005 (Sall et al. 2006). In contrast, the inland fishery employed only 20,000 fishers in 2012 (MPEM, 2018). The fisheries sector is at risk due to overfishing (Diankha et al. 2018; Baldé et al. 2018), marine pollution (Sonko et al. 2017) and climate change (Ba et al. 2016).

To maintain its essential socio-economic and food security role of the fisheries sector in Senegal, aquaculture is being increasingly promoted by the government (Diadhiou et al. 2016). This shift in Senegal follows a worldwide trend. Aquaculture is a vital source of fish products for human consumption. Indeed, it supplies about half of fish products that are consumed 
globally, producing 87 million tons of fish worldwide in 2014 (FAO, 2016). Most of this production comes from the Asian continent (89\%), particularly China. Aquaculture remains marginal in African coastal countries, such as Senegal, but interest in this industry is growing. The actors in the fishing sector, authorities and researchers, are placing significant effort in developing this sector in Senegal. However, the development of aquaculture, especially fish farming, also generates negative impacts on the environment (e.g., Slusarczyk \& Rygielska 2004, Reid et al. 2009; Yokoyama et al. 2015). faeces result to the fish feeding represents about $40-50 \%$ of feed given (dry basis), which are released into fish farm effluent (Souza et al. 2012; Perez et al. 2014). These discharges are sources of pollution in the organic (Amirkolaie, 2011; Bovendeur et al. 1990) and the mineral, like phosphorous (Correll, 1998; Elser et al. 2007, Foy et al. 1991), which can cause damage to the receiving watercourse. Conventional wastewater treatment processes are energy-intensive endeavors that yield little or no recovered resources and often require significant external chemical inputs (Gao et al. 2014).In most countries, where phosphorous and MO discharges are regulated, in freshwater aquaculture, these faeces are precipitated at the bottom of settle ponds before effluent discharge (Cripps \& Bergheim 2000; Koko 2008). After this, pre-treatment sludge (Cripps \& Bergheim 2000) are suitable for use as an agricultural fertilizer (Naylor et al. 1999). An alternative is to integrate this aquaculture with crops that also take this source of pollution into account (Reid et al. 2009). In the overflow system, effluents are used been for a long time to irrigate crops (Castro et al. 2003). However, contemporary challenges in water usage could also be addressed through circular economy solutions in the agricultural sector. They include water efficiency measures, and the reuse of treated wastewater not only for irrigation but also as water for livestock, cleaning water for hydroponics and aquaponics (Goździewicz-Biechońska, 2016; Graber \& Junge 2008). This concept of the circular economy using aquaponic systems has been mostly developed this recent year (e.g., Junge et al. 2017; Forchino et al. 2017; Palm et al. 2018; Palm et al. 2015; Bildariu 
et al. 2011). Still, in this process of the circular economy, it can be assumed that methanation or biogas as an efficient process for the treatment of organic waste has already been proposed but never documented at our knowledge for fish faeces. This approach could be suitable for RAS (Recirculated Aquaculture Systems) and hatcheries because of their high energies requirement.

The anaerobic decomposition of organic matter, under the action of microorganisms, into biogas, is considered a viable alternative source of energy. However, the energy efficiency of biogas depends on the composition of different constitutive gases. There is a positive correlation between the $\mathrm{CH}_{4}$ composition of biogas and its calorific value. For example, the calorific value of one cubic meter of biogas containing $70 \%$ methane is $8.87 \mathrm{kWh}$, whereas the same quantity of pure biogas (100\% methane) generates $12.67 \mathrm{kWh}$ (Mirquez 2011). The production of biogas using organic waste from fish farms represents a potentially beneficial approach that manages effluent and reduces energy bills in fish farm facilities. The digestion of untreated effluent from fish farms shows a significant production of more than $67 \% \mathrm{CH}_{4}$ and up to $78 \% \mathrm{CH}_{4}$ when organic waste has been previously concentrated (Souza et al. 2012). Also, the product resulting from anaerobic digestion (methanogen compost or biodigestate) could be used as an alternative fertilizer. This product is rich in nitrogen and could be used to fertilize food crops, such as sorghum, in Senegal (Maiguizo-Diagne et al. 2016).

Thus, it is necessary to test methanation as a technique for recycling fish faeces. This study investigated the energy potential and fertilizing potential of fish faeces in the framework of developing integrated multi-trophic aquaculture.

\section{Matrials and methods}




\section{Experimental breeding device}

The breeding experiments were carried out in a fish greenhouse. The experimental device consisted of 12 glass aquariums $(50 * 150 * 50 \mathrm{~cm}, 375 \mathrm{~L})$. These aquariums were connected to an air compressor. Each aquarium contained 25 fish of average weight $120 \pm 18 \mathrm{~g}$. The fish, Tilapia (Oreochromis niloticus), were reared for 18 weeks and were fed with "Ranan fish Feed" (Dry matter: $91.21 \pm 0.02 \%$, lipid content: $6 \pm 0.5 \%$, crude protein: $32 \pm 0.9 \%$, ashes: $7.27 \pm$ $0.2 \%$ and raw energy: $16.83 \pm 0.2 \mathrm{MJ} \mathrm{kg}^{-1}$ ). Raanan fish Feed" (Prampram Fishfeed Factory, Ghana (Rurangwa et al. 2015)) was delivered from a large commercial feed company that produces extruded fish feeds, with good palatability (also used in e.g., Devic et al. 2018), and sales on national and regional markets. Fish were fed twice daily (09:00 and 15:00) by hand, and received $3 \%$ of their body weight. The breeding temperature was $29^{\circ} \mathrm{C} \pm 2$, and the oxygen level ranged between 3 and $10 \mathrm{mg} \mathrm{L}^{-1}$ dissolved oxygen. Faeces were collected daily (Choubert et al. 1982; Spyridakis et al. 1989; Peres et al. 2013) between 08:00 and 08:30 using a bag ad hoc, with $100 \mu \mathrm{m}$ mesh, connected to the drain pipe of the aquariums $(1 \mathrm{~m}$, diameter $2 \mathrm{~cm})$. Collected faeces were systematically weighed $( \pm 1 \mathrm{~g})$ and packaged before storage at low temperature $\left(4\right.$ to $\left.8^{\circ} \mathrm{C}\right)$.

\section{Biochemical characterization of fish faeces}

Total carbon, total nitrogen, soluble phosphorus, exchangeable cations (Ca, $\mathrm{Mg}, \mathrm{K}$, and $\mathrm{Na}$ ), and ash contents were analyzed by a certified chemical. Gases $\left(\mathrm{CH}_{4}\right.$ and $\left.\mathrm{CO}_{2}\right)$ were measured using a chromatography system (Agilent 490 Micro GC, Santa Clara, USA).

\section{Measurement of Biochemical Methane Potential}

The principle of methane potential BMP (BMP: Biochemical Methane Potential) is to incubate a small amount of organic substrate and to monitor the amount of biogas and the proportion of 
methane produced. The incubation solution (100 $\mathrm{mL}$ of water) and faeces (10 g of Dry Matter) were placed in hermetically closed bottles $(500 \mathrm{~mL})$. The inoculum used was placed in $10 \mathrm{~L}$ bioreactor containing $400 \mathrm{~g}$ (fresh weight) sediments taken from Lake Redba [a highly salty environment that is rich in extremophilic microorganisms (Gregoire et al. 2009)], $800 \mathrm{~g}$ cow dung and water to make $2 \mathrm{~L}$ in total. Two conditions were tested $(\mathrm{UIFF}=$ raw faeces and IFF $=$ fish faeces supplemented with microbial inoculum issued from a running bioreactor), in addition to a positive control (fish faeces alone) and negative control (solution and inoculum alone). Each treatment was repeated twice. All bottles were placed in an oven $\left(38^{\circ} \mathrm{C}\right)$ and shaken (two to three times per day). The $\mathrm{CH}_{4}$ and $\mathrm{CO}_{2}$ that were produced were measured weekly using micro-chromatography ( $\mu \mathrm{CG}$ ), from week 2 (W2) until the end of methanation (W9).

\section{Fertilizer potential of biodigestates under semi-controlled conditions}

The fertilizing power of Tilapia faeces digestates after methanation was tested on tomato (Solanum lycopersicum) and onion (Allium cepa). Three concentrations of digestate were used: $\mathrm{FP} \_\mathrm{C} 1=50 \mathrm{~g} \mathrm{DM} / 450 \mathrm{ml}, \mathrm{FP} \_\mathrm{C} 2=\mathrm{C} 1$ solution diluted $(1: 2, \mathrm{C} 1 / \mathrm{w})$ and $\mathrm{FP} \_\mathrm{C} 3=\mathrm{C} 1$ solution diluted $(1: 4, \mathrm{C} 1 / \mathrm{w})$. Both varieties tested were pre-germinated on potting soil (Jiffy® substrates TREF, France). Seven-day-old seedlings were transferred to pots containing around $1 \mathrm{~kg}$ sterilized soil. For each cultivated crop, a positive control (NPK, i.e., nitrogen, phosphorus, potassium) was used with five repetitions, in which NPK was added to $0.04 \mathrm{~g} /$ pots for tomatoes and onion. Negative controls (PWS) did not contain any NPK or biodigestates. Fertiliser doses (biodigestate or NPK) were provided one week after transplantation. The plants were watered every two days. As plants grew, we measured the number of leaves, the diameter at the collar and the height of the plants. Also, the dry weight of shoots and roots were measured for each plant. 


\section{Data analysis and statistical tests}

Statistical analyses were carried out on various parameters that were measured on the plants to evaluate the effect of each treatment. Analysis of variance 'ANOVA' was followed by a comparison test (Tukey HSD) using the XLSTAT software (version 2010.3.02).

\section{Results}

\section{Composition of fish faeces}

The total nitrogen content (assayed by the Kjeldahl method) of raw fish faeces (5.5\%) decreased after digestion to $3.3 \%$ (Table 1). Kjeldhal nitrogen was mainly in the form of ammonium and organic nitrogen. These forms of nitrogen were more available and were involved in the methanation phase. Total phosphorus $\left(\mathrm{P}_{\text {total }}\right)$ content was $2.2 \%$ for raw fish faeces and increased after digestion to $2.5 \%$. The observed N/P ratio $(5: 2)$ confirmed that fish faeces are a suitable substrate for methanation.

\section{Biogas production of fish faeces biogas production}

Biogas production of fish faeces was monitored using the standard BMP test. After nine weeks, fish faeces produced more biogas with the inoculum $(\mathrm{IFF}=1100 \mathrm{~mL})$ than fish faeces without the inoculum $(\mathrm{UIFF}=900 \mathrm{~mL})($ Fig. 1). Biogas production from substrate only (UIFF) followed an almost constant rate (resulting in linear accumulation) during the nine weeks of incubation.

\section{Composition of the produced biogas}

Inoculated fish faeces (IFF) produced biogas with lower $\mathrm{CH}_{4}$ content at W2 (14\%) compared to the other weeks. This percentage of methane increased quickly until peaking at W5 (74\%, Fig. 2A), and remained stable at this maximum until W7. From W8, this level decreased to $63 \%$ 
by W9 at the end of the experiment (Fig. 2A). Without inoculum (UIFF), methane production was negligible at W2, but increased quickly and then stabilized over time subsequently. From W4 until the end of the experiment, around $70 \pm 5 \%$ methane was produced, except in W7 where production decreased to $60 \%$ before returning to ca. $70 \%$ in W8 (Fig. 2B).

\section{Agronomic test}

Digestate affected the growth parameters of the two crops differently. Tomato plants (Table 2A) fertilized with raw (FP_C1) or diluted (FP_C2 and FP_C3) biodigestates had significantly different plant height ( $p$-value $>0.05$ ) compared to the control at 90 days after sowing, with these values being similar to those obtained with NPK fertilizer. Only tomato plants fertilized with the most diluted faeces digestate (FP_C3) had significantly different aboveground biomass compared to faeces without fertilization. For most measured parameters, NPK fertilization produced higher values compared to plants without fertilization. In contrast to tomato, onion fertilised with raw (FP_C1) or diluted (FP_C2 and FP_C3) biodigestates showed no significant difference to non-intake plants (Table 2B). Onion fertilised with NPK resulted in significantly taller plants and greater aboveground and root biomass compared to the onion with no inputs or supplemented with digestate.

\section{Discussion}

Fish faeces contain about $18 \%$ dry matter (DM), which is slightly higher than that typically in pig manure, which contains between 5\% and 8\% DM (Quideau et al. 2014). The method used to collect faeces might have a slight influence on the percentage of DM. The use of a low mesh net $(100 \mu \mathrm{m})$ allowed the collection of particles larger than $0.1 \mathrm{~mm}$ over the study period. In comparison, the decantation concentration method would have also collected more faeces but would have required a longer duration to do so. The storage of wet organic matter (OM) at 
ambient temperature is generally not stable. The dry matter content of our substrates was between 15 and $25 \%$, which falls within the reference range of suitability for anaerobic digestion process (Bollon 2012).

Methane production depends on the composition and availability of mineral elements, such as nitrogen. During anaerobic digestion, bacteria use ambient $\mathrm{CO}_{2}$ and various nutritional elements present in the substrate (here fish faeces) to produce methane. Nitrogen is the most limiting factor (Moletta 2008). If nitrogen levels are too low compared to carbon, bacterial metabolism is hindered, with insufficient carbon being transformed to produce methane. In contrast, if nitrogen levels are too high, the ammonia-nitrogen produced inhibits the activity of microorganisms. Nitrogen is an essential element for ensuring good anaerobic digestion.

Fresh cow dung is considered as a suitable substrate for methanation, producing Kjeldhal nitrogen values of $24.3 \mathrm{~g} \mathrm{~kg}^{-1}$ of DM (Anonymous 2013). In comparison, the Kjeldhal nitrogen value of fish faeces was double this value $\left(55.1 \mathrm{~g} \mathrm{~kg}^{-1}\right.$ of DM) (Table 1). This high level of nitrogen implies a low ratio of carbon to nitrogen $(\mathrm{C} / \mathrm{N}=7)$, which is far from the published optimum values of 25 and 30 (Tou et al. 2001). Despite this, we obtained biogas of good quality. Per unit dry weight, (Fig. 1) the biogas accumulation values obtained from fish faeces $(120 \mathrm{~L}$ $\mathrm{kg}^{-1}$ and $90 \mathrm{~L} \mathrm{~kg}^{-1}$ ) were lower than those obtained by Maiguizo-Diagne et al. (2018) from cow dung. These differences could be explained by the diet of cows and the intestinal composition of cows, which naturally contains microorganisms involved in the process of methanation. The production rate of biogas in fish faeces was enhanced by using an inoculum (IFF), especially during the first seven weeks of incubation. After seven weeks, biogas production from IFF became less efficient, which might correspond to the depletion of the substrate in the BMP test (Moletta 2008). This difference in production dynamics between IFF and UIFF might be related to the supply of microorganisms that initiate the production of biogas more quickly. 
The addition of inoculum also slightly increased biogas quality. The calorific value of biogas is strongly correlated with its $\mathrm{CH}_{4}$ content. Interestingly, the quality of biogas produced from tilapia faeces was better than that of cow dung $\left(\sim 58 \% \mathrm{CH}_{4}\right)$, being closer to that of poultry droppings $\left(\sim 63 \%\right.$ of $\left.\mathrm{CH}_{4}\right)$ and leachates $\left(77 \%\right.$ of $\left.\mathrm{CH}_{4}\right)$ (Imen et al. 2009). The percentage of other trace gases present (such as hydrogen sulphide, $\mathrm{H}_{2} \mathrm{~S}$ ) could not be measured in this study; however, such gases should be investigated in future studies because further pre-treatment might be required to avoid the accumulation of toxic $\mathrm{H}_{2} \mathrm{~S}$. Research should also focus on designing methods to recover tilapia faeces efficiently.

Based on Senegalese fish farming case study, the production of biogas using fish faeces can constitute a significant source of energy for hatcheries and RAS production. Fish production in Senegal (and more widely West Africa) is mainly oriented towards tilapia (Senegal River valley strains, Bouaké strains, Lake Manzala strains, Genetically Improved Farmed Tilapia strains). The supply of male fry of this species is determinant to ensure economical profitability. The most used approach is to treat fry with Methyltestosterone (Melard et al. 1995). Another technique "more ecological friendly," which is not widely used, due to his energetic costs, is to spend larvae 28 days after hatching ( $<14$ days post-fertilization) in high-temperature water (34$\left.36^{\circ} \mathrm{C}\right)$. This technique highlighted by increasing the ratio (73-90\%) of males fry in the cohorts (Baroiller et al. 2009; Baras et al. 2001). Another application of energy generated by faeces, close to this previous, is to induce a high ratio of males (Pradeep et al. 2012) and triploids (Razak et al. 1999) of tilapia using heat-shock. Such a technique allows potential alternative in the case where the methane produced by the faeces are used to bring necessary energy to get high-temperature water. If we consider this source of 'energy,' we can estimate the potential production according to the outcomes found in this study and considering, e.g., the goal $(50,000$ tons at 2023) of the Senegalese national plan for the development of aquaculture (in Programme Senegal Emergent: http://senegal-emergent.com/fr/node/330). The potential of energy 
produced using fish faeces was estimated at $18199 \mathrm{MWh}$ (UIFF). This production can be increased using inoculum (IFF) to $24266 \mathrm{MWh}$. For this rough estimation, we considered (i) a high level of Feed Conversion Rate [FCR $=1.2 \mathrm{~kg} \mathrm{~kg}^{-1}$ based on Tshinyama et al. (2018)], (ii) 40\% of feed given [dry matter around 95\% (Köprücü \& Özdemir 2005)] are released as faeces (Guimarães et al. 2008). The production of male tilapia fingerlings using this approach by recycling faeces can minimize the use of the hormone in hatcheries by, being part of a process of the clean land-based culture of fish (Shpigel et al. 1993). Finally, to roughly extend worldwide the conversion method used above and our result and knowing that Tilapia production in 2017 was 5880586 tons, and freshwater aquaculture represented 44 million tons in 2017, it can be estimated an electrical production for 1 and almost 10 million of people, respectively (considering 4400 megawatt hours is the power consumption of about 2000 people). Obviously, such estimation is done under the hypothesis that fish faeces can be collected in a freshwater fish frame which appears easy for RAS (Brown et al. 2011) and less for open one (Cripps et al. 2000) where it remains to develop an ad hoc technique to collect fish faeces.

Also, in the case of Senegal, there is a cold season between November to March. During this season, the ambient temperature can drop, and the temperature of surface water become cold (below $20^{\circ} \mathrm{C}$ ) (Demarcq et al. 1995). In the hatchery, reproduction of tilapia broodstock is limited. Optimum for growing and breeding being around $28^{\circ} \mathrm{C}$ (Baras et al. 2002; 2001). Thus, by producing methane with fish faeces, it will be possible to use this energy to warm up the broodstocks with adequate temperature to maintain reproduction.

As for reproduction, during the growing phase in a closed system, the heating of the water makes it possible to optimize the growth (Likongwe et al. 1996). By recovering the faeces to produce energy that heats the water in rearing tanks, a potential source of pollution is used to 
improve the production and at the same time to eliminate the waste released by fish farming (circular system). The biodigestate resulting in this process can be used as fertilizer for crops. Indeed, the use of biodigestate on tomato and onion vegetable crops produced different responses. Preliminary measurements (first 30 days) of tomato growth parameters showed no significant differences with the negative control (no fertiliser) and lower values compared to the positive control (i.e., with NPK). In comparison, some parameters changed during the second period of measurements period (+90 days). For instance, plant height and the distance between nodes became similar to the NPK control and higher compared to the unfertilized treatment. For aboveground biomass, only the third and most diluted concentration was significantly higher compared to the negative control. In comparison, there was no significant difference in the measured parameters of onion between digestate-fertilised plants and the negative control, with NPK fertilisation being much more efficient.

The current study facilitated provided insights on the fertilising power and assimilation of nutrients resulting from the methanation of fish faeces as aquaculture waste. Paradoxically, the lowest concentration enhanced the growth parameters of tomato the most. This response to biodigestates might be correlated to the raw digestates being too thick and not being sufficiently incorporated into the soil, with some elements remaining on the soil surface. Under this hypothesis, FP_C3 dilution (25\% raw digests and 75\% water) produced the best results because nutrients essential for plant growth were more bioavailable. Alternatively, the high concentrations of digestates might have had some negative effects that counterbalanced the benefits of nutrient supply; however, no strong negative effects were observed for the growth parameters. Digestates were insufficient to enhance the growth parameters of onion compared to NPK under our study conditions. Thus, the fertilizing potential of digestates need to be tested under actual field conditions to evaluate their potential over complete crop cycles, as well as on 
other food crops, such as cereals (e.g., millet, sorghum, corn, rice), which are strongly represented in Senegalese agriculture.

\section{Conclusion}

This study demonstrated that fish faeces has strong biochemical and biogas potential both with and without external methanogen microorganisms, which may be related to its high nitrogen content. This potential was higher than or equal to, the one reported for cow dung (IbnAbubakar \& Ismail 2012; Riggio et al. 2017). These results demonstrate the viability of biogas production from Tilapia faeces. This approach could reduce the energy demand of fish farmers as it could be of relevant interest, e.g., to heat fish water thank for growth performance or fish progeny masculinization by heat-shock and enhance agricultural production as a biofertiliser of plant entering in fish food composition, moving towards integrated and multi-trophic aquaculture. The anaerobic digestion of faeces and the fertilising interest of the waste resulting from this process will reduce the impact of fish farming on the environment, facilitating the economic development of this sector, as encouraged by national authorities in the framework of blue growth. Thus we recommend extension toward open aquaculture frames to increase signiaficantly energy and fertilizer productions, i.e., when an engineering solution will develop cost-efficient ad hoc fish faeces collection systems for open environment. We also recommend to conduct a more agronomic test on bidigestat as fertilizer toward plant of relevant agricultural interest mainly for aquaculture, e.g., entering in fish feed composition. In the framework of blue growth (Brugère et al. 2015; Kokkinou et al. 2018), methanogenic and fertilizing potential of aquaculture waste provide locally net benefit to the ocean economy and environment, and do not disrupt principles of social equity. The results should be applied to reduce poverty, a priority of the blue blow growth. A promising application could be oriented toward small scale farms to reach energy self-sufficiency in developing countries. 


\section{Acknowledgments}

This work is dedicated to $\mathrm{M}$. Ibou NDAO adaptive father of the first author Mrs Ndeye Aida NDIAYE, died during the redaction of this manuscript. The ISRA CST drove this interdisciplinary work in 2015 as a transversal action with the support of ongoing research projects at ISRA/LCM-LNRPV-IeSol: The work was supported by First BIOGAZ project (MESR) in LCM, in CRODT by the AWA project (IRD-BMBF, grant 01DG12073E; www.awa.ird.fr "ecosystem approach to the management of fisheries and the marine environment in West African waters") implemented by the Sub Regional Fisheries Commission (SRFC/CSRP), PamTilapia (FNRAA) project as part of the World Bank's West Africa Productivity Program Phase 2 (2016-2017) and the European Preface project (https://preface.w.uib.no/) which has received funding from the FP7 Program for research, technological development and demonstration under license agreement no. 603521. Chemical analysis has been done by LAMA (ISO9001 certified laboratory) of IRD (US 191 Imago, Senegal). Finally, this work was also supported by the blue belt initiative (www.laceinturebleue.org) a collaborative platform to act together and put into practice innovative solutions for the adaptation of the fisheries and aquaculture sectors to climate change and for the resilience of oceans and climate.

\section{References}

Anonymous ( 2013) Méthanisation de fumiers bovin et volaille Impact du stockage du fumier Essais pilote et potentiel énergétique. ADEME (Ed). Direction Régionale Bourgogne, pp. 12, https://bourgogne-franche-comte.ademe.fr/sites/default/files/methanisation-fumiers-2013.pdf.

Amirkolaie AK (2011) Reduction in the environmental impact of waste discharged by fish farms through feed and feeding. Reviews in Aquaculture, 3, 19-26.

Auger P-A, Gorgues T, Machu E, Aumont O, Brehmer P (2016) What drives the spatial variability of primary productivity and matter fluxes in the north-west African upwelling system? A modelling approach. Biogeosciences, 13, 6419-6440, https://doi.org/10.5194/bg-13-6419-2016.

Ba A, Schmidt J, Dème M, Lancker K, Chaboud C, Cury P, Thiao D, Diouf M, Brehmer P (2017) Profitability and economic drivers of small pelagic fisheries in West Africa: A twenty year perspective. Marine Policy, 76, 152-158.

Baldé BS, Brehmer P, Sow FN, Ekau W, Kantoussan J, Fall M, Diouf M (2018) Population dynamics and stock assessment of Ethmalosa fimbriata in Senegal call for fishing regulation measures. Regional Studies in Marine Science, 24, 165-173, https://doi.org/10.1016/j.rsma.2018.08.003.

Baras E, Jacobs B, Mélard C (2001) Effect of water temperature on survival, growth and phenotypic sex of mixed (XX-XY) progenies of Nile tilapia Oreochromis niloticus. Aquaculture, 192, 187199.

Baras E, Mpo'N'Tcha A, Driouch H, Prignon C, Mélard C (2002) Ontogenetic variations of thermal optimum for growth, and its implication on thermolabile sex determination in blue tilapia. Journal of Fish Biology, 61, 645-660.

Baroiller J-F, D'Cotta H, Bezault E, Wessels S, Hoerstgen-Schwark G (2009) Tilapia sex determination: where temperature and genetics meet. Comparative Biochemistry and Physiology Part A: Molecular \& Integrative Physiology, 153, 30-38. 
Blidariu F, Grozea A (2011) Increasing the economical efficiency and sustainability of indoor fish farming by means of aquaponics-review. Scientific Papers Animal Science and Biotechnologies, 44, 1-8.

Bollon J (2012) Etude des mécanismes physiques et de leur influence sur la cinétique de méthanisation en voie sèche: essais expérimentaux et modélisation. INSA de Lyon, https://tel.archivesouvertes.fr/tel-00770658/.

Bovendeur J, Zwaga A, Lobee B, Blom J (1990) Fixed-biofilm reactors in aquacultural water recycle systems: effect of organic matter elimination on nitrification kinetics. Water Research, 24, 207213.

Bowen A, Hepburn C (2014) Green growth: an assessment. Oxford Review of Economic Policy, 30, 407422, https://doi.org/10.1093/oxrep/gru029.

Brown N, Eddy S, Plaud S (2011) Utilization of waste from a marine recirculating fish culture system as a feed source for the polychaete worm, Nereis virens. Aquaculture, 322, 177-183.

Brugère C, Aguilar-Manjarrez J, Beveridge MC, Soto D (2018) The ecosystem approach to aquaculture 10 years on-a critical review and consideration of its future role in blue growth. Reviews in Aquaculture, https://doi-org.acces.bibl.ulaval.ca/10.1111/raq.12242.

Castro RS, Azevedo CMB, Bezerra-Neto F (2006) Increasing cherry tomato yield using fish effluent as irrigation water in Northeast Brazil. Scientia Horticulturae, 110, 44-50.

Choubert G, De la Noue J, Luquet P (1982) Digestibility in fish: improved device for the automatic collection of feces. Aquaculture, 29, 185-189. https://doi.org/10.1016/0044-8486(82)90048-5.

Correll DL (1998) The role of phosphorus in the eutrophication of receiving waters: A review. Journal of Environmental Quality, 27, 261-266.

Cripps SJ, Bergheim A (2000) Solids management and removal for intensive land-based aquaculture production systems. Aquacultural engineering, 22, 33-56.

Delgadillo Mirquez LR (2011) Modélisation du devenir des micropolluants organiques au cours de la digestion anaérobie de boues contaminées. In: Ecole Doctorale de Sciences des ProcédésScience des Aliments. Université Montpellier 2, http://agris.fao.org/agrissearch/search.do?recordID=FR2014006361.

Demarcq H, Citeau J (1995) Sea surface temperature retrieval in tropical area with Meteosat: the case of the Senegalese coastal upwelling. International Journal of Remote Sensing, 16, 1371-1395.

Deme M, Diadhiou HD, NDiaye V, Thiam D (2005) Synthèse des résultats d'enquêtes du Projet Valeurs et capitalisation des données d'inventaire sur les ressources continentales au Sénégal. (ed ISRA/CRODT). CRODT / CSE, ISRA/CRODT, Dakar, Sénégal, pp. 24.

Devic E, Leschen W, Murray F, Little DC (2018) Growth performance, feed utilization and body composition of advanced nursing Nile tilapia (Oreochromis niloticus) fed diets containing Black Soldier Fly (Hermetia illucens) larvae meal. Aquaculture Nutrition, 24, 416-423, https://doi.org/10.1111/anu.12573.

Diadhiou HD, Deme M, Mbaye A, Brehmer P (2016) Le développement de l'Aquaculture au Sénégal : potentialités, production et difficultés., Dakar 2015, 113-113. p, http://horizon.documentation.ird.fr/exl-doc/pleins textes/divers17-12/010071832.pdf.

Diankha O, Ba A, Brehmer P, Brochier T, Sow BA, Thiaw M, Gaye AT, Ngom F, Demarcq H (2018) Contrasted optimal environmental windows for both sardinella species in Senegalese waters. Fisheries oceanography, 27, 351-365, https://doi.org/10.1051/alr/2017027. 
Diankha O, Demarcq H, Fall M, Thiao D, Thiaw M, Sow BA, Gaye AT, Brehmer P (2017) Studying the contribution of different fishing gears to the Sardinella small-scale fishery in Senegalese waters. Aquatic Living Resources, 30, 27, https://doi.org/10.1051/alr/2017027.

Dupont N (2010) Valorisation du biogaz de fermentation: combustion catalytique. Université Claude Bernard-Lyon I, https://tel.archives-ouvertes.fr/tel-00816867/.

Elser JJ, Bracken ME, Cleland EE, Gruner DS, Harpole WS, Hillebrand H, Ngai JT, Seabloom EW, Shurin JB, Smith JE (2007) Global analysis of nitrogen and phosphorus limitation of primary producers in freshwater, marine and terrestrial ecosystems. Ecology letters, 10, 1135-1142.

FAO (2016) La Situation mondiale des pêches et de l'aquaculture. 2016 : contribuer à la sécurité alimentaire et à la nutrition de tous., Rome, 224 p, http://www.fao.org/3/a-i5555f.pdf.

Forchino A, Lourguioui H, Brigolin D, Pastres R (2017) Aquaponics and sustainability: The comparison of two different aquaponic techniques using the Life Cycle Assessment (LCA). Aquacultural Engineering, 77, 80-88.

Foy R, Rosell R (1991) Loadings of nitrogen and phosphorus from a Northern Ireland fish farm. Aquaculture, 96, 17-30.

Fujibayashi M, Tanaka N, Hashido S, Takasawa A, Nishimura O (2018) Nutritional quality of fish faeces is enhanced by highly unsaturated fatty acid-producing heterotrophic protozoa. Acta Oecologica, 89, 21-26, https://doi.org/10.1016/j.actao.2018.04.003.

Gao H, Scherson YD, Wells GF (2014) Towards energy neutral wastewater treatment: methodology and state of the art. Environmental science: Processes \& impacts, 16, 1223-1246, https://doi.org/10.1039/C4EM00069B

Goździewicz-Biechońska J (2016) The role of agriculture in the circular economy (perspectives for legislation and policy). Przeglad Prawa Rolnego, 1(18), 81-95.

Graber A, Junge R (2009) Aquaponic Systems: Nutrient recycling from fish wastewater by vegetable production. Desalination, 246, 147-156.

Grégoire P, Fardeau M, Guasco S, Bouanane A, Michotey V, Bonin P, Dubourg K, Cambar J, Ollivier B (2009) Les micro-organismes de l'extrême. La Presse thermale et climatique, 146, 49-61.

Guimaraes IG, Pezzato LE, Barros MM, Tachibana L (2008) Nutrient digestibility of cereal grain products and by-products in extruded diets for Nile tilapia. Journal World Aquaculture Society, 39, 781-789.

Imen S, Ismail T, Sami S, Fathi A, Khaled M, Ahmed G, Latifa B (2009) Characterization and anaerobic batch reactor treatment of Jebel Chakir Landfill leachate. Desalination, 246, 417-424, https://doi.org/10.1016/j.desal.2008.04.056.

Junge R, König B, Villarroel M, Komives T, Jijakli M (2017) Strategic points in aquaponics. Multidisciplinary Digital Publishing Institute. Water, 9, 182. https://doi:10.3390/w9030182.

Kebe M, Le Reste L (1993) Conflits liés au secteur des pêches sénégalaises. In: Gestion des ressources côtières et littorales du Sénégal. Actes de l'Atelier de Gorée (Sénégal), 27-29 juillet 1992 (eds Diaw AT, Bâ AP, Bouland P, Diouf PS), UICN, Gland, Suisse, pp. 379-392.

Kokkinou A, Korres GM, Papanis E (2018) Blue smart economy-A current approach towards growth. Smart Cities and Regional Development (SCRD) Journal, 2, 81-90, http://www.scrd.eu/index.php/scrd/article/view/40/34.

Koko KDG (2007) Une stratégie nutritionnelle de réduction du phosphore (P) dans les effluents aquacoles: l'alimentation en phase des truites arc-en-ciel (Oncorhynchus mykiss) avec alternances d'un régime carencé et d'un régime équilibré en P. Laval University, pp. 93, http://hdl.handle.net/20.500.11794/20376. 
Köprücü K, Özdemir Y (2005) Apparent digestibility of selected feed ingredients for Nile tilapia (Oreochromis niloticus). Aquaculture, 250, 308-316.

Maiguizo-Diagne H, Nadieline CV, Ndiaye-Cisse MF, Ndiaye NA, Ndoye I, Fall S ( 2016) Effets de biofertilisants et biodigestats des fientes de volaille et bouse de vache sur la croissance du maiis (Zea mays) et du sorgho (Sorghum sp). Afrique Science, 12, http://www.afriquescience.net/numero4.html.

Mélard C (1995) Production of a high percentage of male offspring with 17a-ethynylestradiol sexreversed Oreochromis aureus. I. Estrogen sex-reversal and production of F2 pseudofemales. Aquaculture, 130, 25-34.

Moletta R (2011) Méthanisation de la biomasse., Paris, 552 p, https://www.techniquesingenieur.fr/base-documentaire/procedes-chimie-bio-agro-th2/bioprocedes-dans-les-domainesde-l-energie-et-de-l-environnement-42161210/methanisation-de-la-biomasse-bio5100/.

MPEM (2018) Lettre de politique sectorielle de Développement de la Pêche et de l'Aquaculture (LPSDPA) 2016-2023. Ministère de la Pêche et de l’Economie Maritime, Dakar-Sénégal, pp. 37.

Naylor SJ, Moccia RD, Durant GM (1999) The chemical composition of settleable solid fish waste (manure) from commercial rainbow trout farms in Ontario, Canada. North Amercican Journal of Aquaculture, 61, 21-26.

Palm HW, Knaus U, Appelbaum S, Goddek S, Strauch SM, Vermeulen T, Jijakli MH, Kotzen B (2018) Towards commercial aquaponics: A review of systems, designs, scales and nomenclature. Aquaculture international, 26, 813-842.

Palm HW, Nievel M, Knaus U (2015) Significant factors affecting the economic sustainability of closed aquaponic systems. Part III: Plant units. AACL Bioflux, 8, 89-106.

Patil PG, Virdin J, Diez SM, Roberts J, Singh A (2016) Toward a blue economy: a promise for sustainable growth in the Caribbean, World Bank, https://doi.org/10.1596/25061.

Peres H, Guerreiro I, Pérez-Jiménez A, Oliva-Teles A (2013) A non-lethal faeces collection method for Senegalese sole (Solea senegalensis) juveniles. Aquaculture, 414-415, 100-102, https://doi.org/10.1016/j.aquaculture.2013.07.035.

Pérez Ó, Almansa E, Riera R, Rodriguez M, Ramos E, Costa J, Monterroso Ó (2014) Food and faeces settling velocities of meagre (Argyrosomus regius) and its application for modelling waste dispersion from sea cage aquaculture. Aquaculture, 420-421, 171-179, https://doi.org/10.1016/j.aquaculture.2013.11.001.

Pradeep PJ, Srijaya TC, Papini A, Chatterji AK (2012) Effects of triploidy induction on growth and masculinization of red tilapia [Oreochromis mossambicus (Peters, 1852) $\times$ Oreochromis niloticus (Linnaeus, 1758)]. Aquaculture, 344-349, 181-187, https://doi.org/10.1016/j.aquaculture.2012.03.006.

Quideau P, Levasseur P, Charpiot A, Lendormi T, Guiziou F (2014) Combined effects of rapid discharge of manure and their anaerobic digestion. Innovations Agronomiques, 34, 309-320, https://hal.archives-ouvertes.fr/hal-01199419.

Razak S, Hwang, G.L., Rahman, M. (1999) Growth performance and gonadal development of growth enhanced transgenic tilapia Oreochromis niloticus (L.) following heat-shock-induced triploidy. Marine Biotechnology, 1, 533-544, https://doi.org/10.1007/PL00011808.

Reid GK, Liutkus M, Robinson SMC, Chopin TR, Blair T, Lander T, Mullen J, Page F, Moccia RD (2009) A review of the biophysical properties of salmonid faeces: implications for aquaculture waste dispersal models and integrated multi-trophic aquaculture. Aquaculture Research, 40, 257-273, https://doi.org/10.1111/j.1365-2109.2008.02065.x. 
Sall A., Dème M., Diouf P. S. ( 2006) L'évaluation des emplois dans les pêcheries maritimes artisanales sénégalaises. pp. 44 p.

Shpigel M, Neori A, Popper DM, Gordin H (1993) A proposed model for "environmentally clean" landbased culture of fish, bivalves and seaweeds. Aquaculture, 117, 115-128.

Ślusarczyk M, Rygielska E (2004) Fish Faeces as the Primary Source of Chemical Cues Inducing Fish Avoidance Diapause in Daphnia Magna. Hydrobiologia, 526, 231-234, https://ink.springer.com/article/10.1023/B:HYDR.0000041599.56610.b4.

Sonko A, Brehmer P, Constantin de Magny G, Gassama A, Diop C, Cisse I, Fall M, Finot L, Henry M, Kande Y (2017) Study of the overall toxicity, water quality and microplastics of the peninsula of Cape Verde, Senegal. In Brehmer P., Ba B., Kraus G. (ed.) International conference ICAWA 2016 : extended book of abstract : the AWA project : ecosystem approach to the management of fisheries and the marine environment in West African waters.Dakar : SRFC/CSRP p. 79-80. http://horizon.documentation.ird.fr/exl-doc/pleins textes/divers18-01/010072126.pdf

Souza DSM, Ramos APD, Nunes FF, Moresco V, Taniguchi S, Guiguet Leal DA, Sasaki ST, Bícego MC, Montone RC, Durigan M, Teixeira AL, Pilotto MR, Delfino N, Franco RMB, de Melo CMR, Bainy ACD, Barardi CRM (2012) Evaluation of tropical water sources and mollusks in southern Brazil using microbiological, biochemical, and chemical parameters. Ecotoxicology and Environmental Safety, 76, 153-161, https://doi.org/10.1016/j.ecoenv.2011.09.018.

Spyridakis P, Metailler R, Gabaudan J, Riaza AP (1989) Studies on nutrient digestibility in European sea bass (Dicentrarchus labrax). Aquaculture, 77, 61-70, https://doi.org/10.1016/0044$\underline{8486(89) 90021-5 .}$.

Thiaw M, Auger P-A, Ngom F, Brochier T, Faye S, Diankha O, Brehmer P (2017) Effect of environmental conditions on the seasonal and inter-annual variability of small pelagic fish abundance off North-West Africa: The case of both Senegalese sardinella. Fisheries Oceanography, 26, 583-601, https://doi.org/10.1111/fog.12218.

Tiedemann M, Brehmer P (2017) Larval fish assemblages across an upwelling front: Indication for active and passive retention. Estuarine, Coastal and Shelf Science, 187, 118-133, https://doi.org/10.1016/j.ecss.2016.12.015.

Tou I, Igoud S, Touzi A (2001) Production de Biométhane à partir des Déjections Animales. Rev. Energ. Ren.: Production et 103-108, https://www.cder.dz/download/bio_17.pdf.

Tshinyama A, Proulx E, Deschamps M-H, Okitayela F, Khasa D, Vandenberg G (2018) Contribution to the Identification of a Local and Available Food Source for Sustainable Production of Nile Tilapia (Oreochromis niloticus, Linnaeus, 1758) in the Democratic Republic of Congo. Tropicultura, 36, 109-122.

Yokoyama H, Tadokoro D, Miura M (2015) Quantification of waste feed and fish faeces in sediments beneath yellowtail pens and possibility to reduce waste loading by co-culturing with sea cucumbers: an isotopic study. Aquaculture Research, 46, 918-927, https://doi.org/10.1111/are.12247. 


\section{Legend of the figures}

Figure 1 Biogas accumulated. Cumulative biogas production from fish faeces (Oreochromis niloticus) with the inoculum (IFF) versus without the inoculum (UIFF) in methanogenic communities.

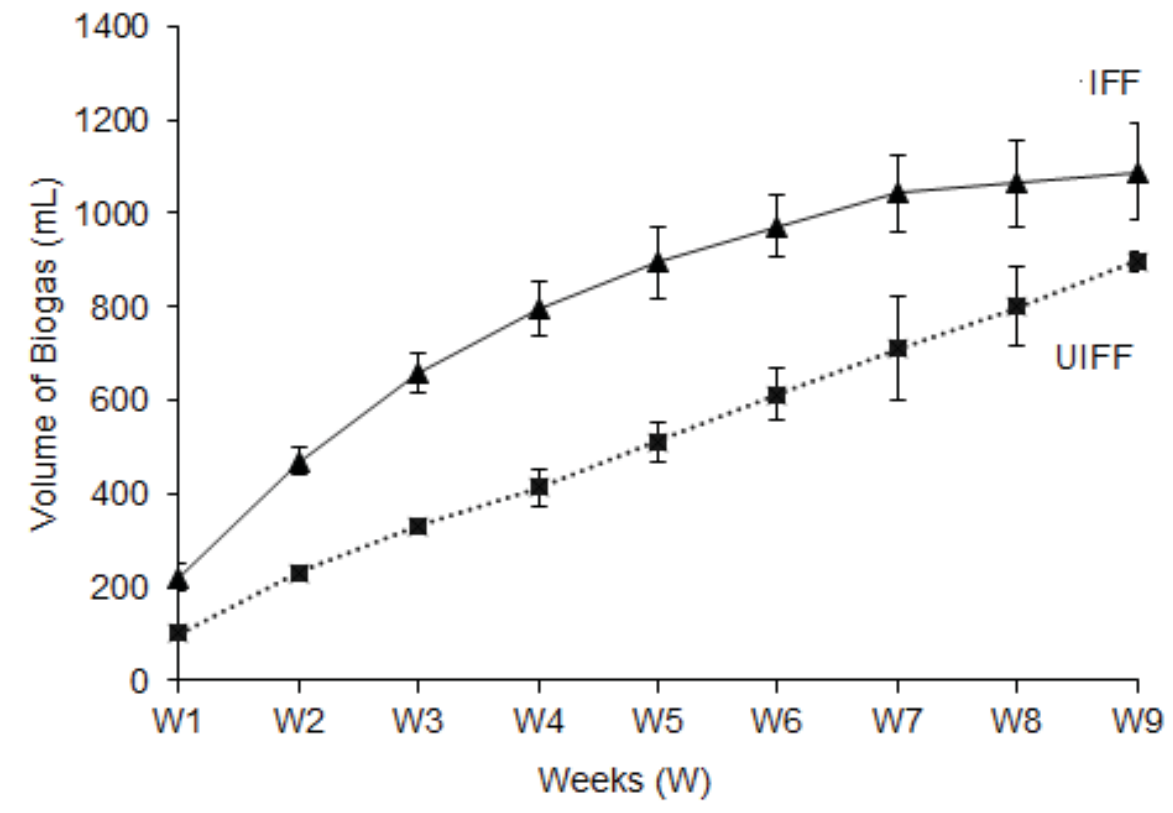


Figure 2 Proportion of methane $\left(\mathrm{CH}_{4}\right.$ : black hatched $)$ and carbon dioxide $\left(\mathrm{CO}_{2}\right.$; white with a black point) in biogas produced from the fourth to ninth week (W) from inoculated tilapia (Oreochromis niloticus) faeces (IFF, in grey) and tilapia faeces without the inoculum (UIFF, in white).

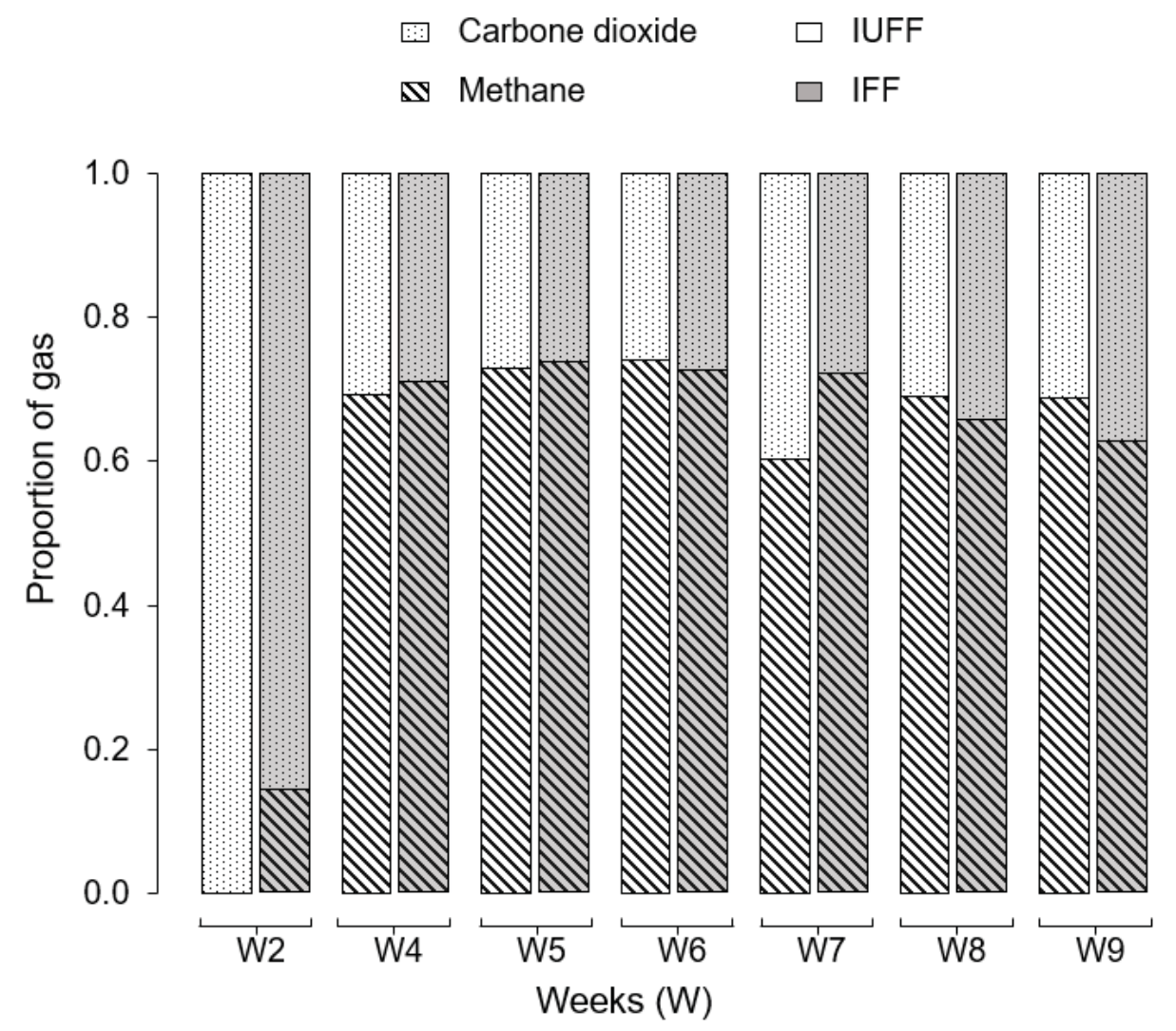


Table 1 Biochemical composition of Tilapia (Oreochromis niloticus) faeces and digestate during breeding (in ppm). FF = raw faeces; FFD = digestate from FF after methanisation; $\mathrm{C}$ : carbon; N: nitrogen; P: phosphorus; Ca: calcium; Mg: magnesium; Na: sodium; K: potassium; nd: not determined

\begin{tabular}{lccccccccc}
\hline Sample & $\mathrm{C}$ & $\mathrm{N}$ & $\mathrm{C} / \mathrm{N}$ & & $\mathrm{P}$ total & $\mathrm{Ca}$ & $\mathrm{Mg}$ & $\mathrm{Na}$ & $\mathrm{K}$ \\
\hline FF & 392300 & 55105 & 7.11 & & 22905 & 48145 & 2251 & 827 & 833 \\
FFD & nd & 33548 & nd & & 25530 & 60727 & 12642 & 8765 & 41278 \\
Ratio & - & 0.61 & - & & 1.11 & 1.26 & 5.62 & 10.6 & 49.55 \\
FFD/FF & - & & & & & & & &
\end{tabular}


Table 2 Effect of different concentrations of Tilapia (Oreochromis niloticus) faeces biodigestates on certain key growth parameters, i.e., quantity of leaves, height of plants $(\mathrm{cm})$, collar diameter (mm), tomato internodes $(\mathrm{cm})$ and dry weight $(\mathrm{g})$, for (a) tomatoes (Solanum lycopersicum) and (b) onion (Allium cepa). Values form the same column are compared and when not sharing identical letters were significantly different $(p$-value $<0.05) . \mathrm{PWS}=$ plant without supply $($ control $) ; \mathrm{FP} \_\mathrm{C} 1=$ raw biodigestate $(100 \%) ; \mathrm{FP} \_\mathrm{C} 2=\mathrm{FP} \_\mathrm{C} 1$ diluted at $50 \%$ (v/v); FP_C3 = FP_C1 diluted at $25 \%$ (v/v); Nitrogen phosphorus potassium NPK: fertiliser 12-12-16; Shoots = aboveground biomass; Roots = root biomass

a)

\begin{tabular}{|c|c|c|c|c|c|c|c|c|c|c|c|}
\hline \multicolumn{2}{|c|}{ Tomato } & \multicolumn{2}{|c|}{ Quantity of leaves } & \multicolumn{2}{|c|}{ Height of plants } & \multicolumn{2}{|c|}{ Collar diameter } & \multicolumn{2}{|c|}{ Internodes } & \multicolumn{2}{|c|}{ Dry weight } \\
\hline & (day) & 30 & 90 & 30 & 90 & 30 & 90 & 30 & 90 & Shoots & Roots \\
\hline \multirow{5}{*}{ 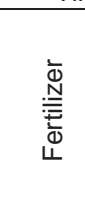 } & PWS & $57.0^{b}$ & $68.2^{\mathrm{b}}$ & $18.4^{b}$ & $38.7^{b}$ & $4.2^{\mathrm{b}}$ & $5.6^{\mathrm{b}}$ & $7.4^{\mathrm{b}}$ & $10.2^{\mathrm{a}}$ & $3.56^{c}$ & $0.73^{b}$ \\
\hline & FP_C3 & $69.8^{\mathrm{b}}$ & $79.0^{\mathrm{b}}$ & $19.4^{b}$ & $48.2^{\mathrm{a}}$ & $4.8^{\mathrm{b}}$ & $6.0^{\mathrm{ab}}$ & $8.0^{\mathrm{b}}$ & $10.6^{a}$ & $5.02^{\mathrm{ab}}$ & $0.78^{\mathrm{b}}$ \\
\hline & FP_C2 & $71.2^{\mathrm{b}}$ & $80.8^{b}$ & $20.5^{b}$ & $52.8^{a}$ & $4.4^{\mathrm{b}}$ & $5.8^{b}$ & $8.0^{\mathrm{b}}$ & $12.2^{\mathrm{a}}$ & $4.72 b^{c}$ & $0.87^{\mathrm{ab}}$ \\
\hline & FP_C1 & $62.4^{\mathrm{b}}$ & $72.2^{\mathrm{b}}$ & $19.0^{b}$ & $57.0^{\mathrm{a}}$ & $5.2^{\mathrm{b}}$ & $5.6^{\mathrm{b}}$ & $8.4^{\mathrm{ab}}$ & $13.0^{\mathrm{a}}$ & $3.59^{c}$ & $0.78^{\mathrm{b}}$ \\
\hline & NPK & $98.0^{\mathrm{a}}$ & $107.6^{\mathrm{a}}$ & $29.7^{a}$ & $57.2^{\mathrm{a}}$ & $7.0^{\mathrm{a}}$ & $7.6^{\mathrm{a}}$ & $9.6^{\mathrm{a}}$ & $11.4^{\mathrm{a}}$ & $6.31^{\mathrm{a}}$ & $1.29^{\mathrm{a}}$ \\
\hline
\end{tabular}


b)

\begin{tabular}{|c|c|c|c|c|c|c|c|c|c|}
\hline \multicolumn{2}{|l|}{ Onion } & \multicolumn{2}{|c|}{ Quantity of leaves } & \multicolumn{2}{|c|}{ Height of plants } & \multicolumn{2}{|c|}{ Collar diameter } & \multicolumn{2}{|c|}{ Dry weight } \\
\hline & (day) & 30 & 90 & 30 & 90 & 30 & 90 & Shoots & Roots \\
\hline \multirow{5}{*}{ 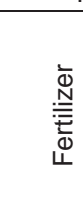 } & PWS & $6.0^{\mathrm{ab}}$ & $7.0^{\mathrm{ab}}$ & $13.5^{\mathrm{b}}$ & $14.1^{b}$ & $1.0^{b}$ & $1.6^{\mathrm{b}}$ & $54^{b}$ & $26^{\mathrm{b}}$ \\
\hline & FP_C3 & $4.0^{b}$ & $5.0^{\mathrm{b}}$ & $11.2^{\mathrm{b}}$ & $13.2^{\mathrm{b}}$ & $0.8^{b}$ & $1.4^{\mathrm{b}}$ & $66^{b}$ & $38^{b}$ \\
\hline & FP_C2 & $5.0^{\mathrm{ab}}$ & $7.0^{\mathrm{ab}}$ & $13.8^{\mathrm{b}}$ & $16.5^{b}$ & $1.2^{\mathrm{b}}$ & $1.8^{\mathrm{b}}$ & $82^{b}$ & $28^{b}$ \\
\hline & FP_C1 & $5.0^{\mathrm{ab}}$ & $7.0^{\mathrm{ab}}$ & $11.5^{\mathrm{b}}$ & $14.0^{\mathrm{b}}$ & $1.2^{\mathrm{b}}$ & $1.6^{\mathrm{b}}$ & $50^{\mathrm{b}}$ & $26^{\mathrm{b}}$ \\
\hline & NPK & $8.0^{\mathrm{a}}$ & $9.0^{\mathrm{a}}$ & $31.3^{\mathrm{a}}$ & $40.0^{a}$ & $4.2^{\mathrm{a}}$ & $6.4^{\mathrm{a}}$ & $540^{a}$ & $158^{a}$ \\
\hline
\end{tabular}

